IRSH 58 (20I3), pp. 9-38 doi:I0.10I7/S00208590I 2000788

(c) 2013 Internationaal Instituut voor Sociale Geschiedenis

\title{
Servile Sentinels of the City: Private Security Guards, Organized Informality, and Labour in Interactive Services in Globalized India
}

\author{
NANDINI GoOPTU \\ Department of International Development, University of Oxford \\ Queen Elizabeth House, Mansfield Road, Oxford OXI $3 T B$, \\ United Kingdom
}

E-mail: Nandini.Gooptu@qeh.ox.ac.uk

ABSTRACT: Through a study of private security guards in urban India, this paper investigates emerging labour processes in the increasingly dominant private corporate sector of Third World rising economies, in the wake of economic liberalization and globalization. To meet the escalating need for labour in interactive services, a vast cadre of low-paid, casual workers has emerged, working under a regime of organized informality. Recruitment and training here are systematically institutionalized and formalized by private agencies, with the imprimatur of the state, but employment relations remain informal and insecure. The paper examines forms of labour subordination and a culture of servility at the workplace, as well as embodied work and emotional labour that characterize low-end service jobs. The paper shows how workers' political subjectivity and their perception of class difference and social identity are shaped by cultural and social interaction at work and how these relate to wider democratic politics and citizenship.

\section{INTRODUCTION}

The history and recent transition in the nature of informality and labour in developing countries have generated much scholarly discussion of late. The informal sector of petty production and self-employment has been theorized as the subsistence or need economy of non-corporate capital, located outside the zone of corporate capital and the accumulation economy, but necessary for the reproduction of post-colonial capitalism in the era of neo-liberal globalization. ${ }^{\mathrm{I}}$ It is also recognized that informality in

I. Kalyan Sanyal, Rethinking Capitalist Development: Primitive Accumulation, Governmentality and Post-Colonial Capitalism (London [etc.], 2007), ch. 5; Partha Chatterjee, Lineages of Political Society: Studies in Postcolonial Democracy (New York, 20I I), pp. 208-234. 
labour use and "flexploitation" 2 are rampant and proliferating within the circuit of capital, particularly in the increasingly dominant private corporate sector of Third World rising economies, such as India. ${ }^{3}$ Here, one of the most important emerging features of the labour market is the regularization of informality, with various forms of informal and casual work, particularly service work, hitherto located outside the domain of the organized sector of capital, being increasingly brought within its ambit, albeit on an informal basis. The National Commission on Enterprises in the Unorganized Sector in India, for instance, highlights the growing incidence of informality within the formal sector, where the creation of new employment has been almost exclusively of an informal nature in recent decades, in the wake of the liberalization and globalization of the economy in the I990s. ${ }^{4}$

In the West, well-established regimes of labour protection were dismantled in recent decades, leading to the informalization of hitherto formal employment. In India, in contrast, the labour market has been historically dominated by the informal sector, with only a minority of workers being in formal employment with labour rights. With globalization, however, employment has risen in the organized corporate sector. This sector, supposedly subjected to labour regulations and offering high quality work, has, in fact replicated the insecurity, low pay, and poor conditions of informal work. Additionally, this process in India has its distinctive character, being inflected by customary and pre-existing forms of labour subordination, relating to hierarchies of caste and status, as we shall see below. It is, however, rarely appreciated that, while labour relations and terms of engagement remain casual and insecure in the organized sector, yet the urgent need for labour in the rapidly expanding private corporate sector has meant that mobilization, recruitment, and training of workers are now increasingly highly organized and institutionalized processes, with the imprimatur and involvement of the state.

The dynamics of such organized informality are explored in this paper, to reveal the simultaneous presence of both formal and informal processes within the same labour regime. From this perspective, the paper probes

2. Pierre Bourdieu, Acts of Resistance: Against the New Myths of our Time (Cambridge, 1998), p. 85. 3. Sanyal, Rethinking Capitalist Development, pp. 237-242; Amitabh Kundu, "Urban System in India: Trends, Economic Base, Governance, and a Perspective of Growth under Globalization", in Waquar Ahmed, Amitabh Kundu, and Richard Peet (eds), India's New Economic Policy: A Critical Analysis (New York [etc.], 201 I), pp. 68-69.

4. Arjun K. Sengupta (Chairman), Report on Conditions of Work and Promotion of Livelihoods in the Unorganized Sector (National Commission for Enterprises in the Unorganized Sector, New Delhi, 2008), pp. 3-4. According to this report, unorganized or informal workers "consist of those working in the unorganized enterprises or households, excluding regular workers with social security benefits, and the workers in the formal sector without any employment/ social security benefits provided by the employers", p. 3 . 
the experience of workers, and analyses the process of creation of a "precariat", within the organized private corporate sector. While informalization refers mainly to the erosion of previously existing job security or workplace rights, the term precariat draws attention to precariousness, which includes the lack of a secure niche in the labour market, and the absence of steady occupational and employment opportunities relating to a particular set of skills, thus preventing upward social mobility and a stable career trajectory. ${ }^{5}$ Precariousness has a political dimension too, relating to the lack of representational security, because the interests and needs of the precariat are usually not ideologically articulated or institutionally represented either through occupational associations and trade unions or political parties. ${ }^{6}$

Precariousness, previously largely a feature of the informal sector, is now increasingly prevalent within the urban organized sector in service work. India's recent urbanization has occurred within the context of a middle-class consumer revolution, and has been marked by a phenomenal expansion of what Shearing and Stenning have termed "mass private property", ${ }^{7}$ or privately owned and managed large-scale consumer facilities for public use. Urban areas have witnessed a hitherto unprecedented proliferation of private hospitals, educational institutions, leisure and entertainment venues, hotels and hospitality units, large scale organized retail outlets, and shopping malls. Maintenance, cleaning, catering, and housekeeping in such mass private property, as well as the protection, safety, and security of such commodified spaces and their owners and users, have led to both an immense surge in demand for suitably trained labour and a radical transformation in the nature of work at the bottom of the urban formal sector, which is now dominated by "immaterial labour", engaged in generating surplus value through the production of immaterial services, rather than manufacturing material goods, as conceptualized by Hardt and Negri. ${ }^{8}$ Further, a recent study underscores that India's modern service sector of finance and ICT, usually associated with high-end skilled jobs, is also the employment destination of a large number of low-skilled service workers. ${ }^{9}$

Urban low-level service workers, such as guards, cleaners, and cooks, had in the past been largely confined to casual work in domestic service and the unorganized private sector, where recruitment and control of labour had been

5. Guy Standing, The Precariat: The New Dangerous Class (London, 2011), p. Iо. On "precarization", see Zygmunt Bauman, Liquid Modernity (Cambridge, 2000), pp. 160-167.

6. Standing, The Precariat, p. Io.

7. Clifford D. Shearing and Philip C. Stenning, "Private Security: Implications for Social Control", Social Problems, 30 (1983), pp. 493-506, 496; idem, "Modern Private Security: Its Growth and Implications", Crime and Justice, 3 (198I), pp. 193-245, 240.

8. Michael Hardt and Antonio Negri, Empire (Cambridge, MA [etc.], 2000), pp. 289-294.

9. Barry Eichengreen and Poonam Gupta, "The Service Sector as India's Road to Economic Growth", National Bureau of Economic Research: Working Paper, No. 16757 (February 201 I), pp. I0-I2. 
personalized and, at times, informally organized through the social institutions of caste and gender. However, as noted above, these forms of service work have now seen a major expansion within the urban formal sector. Private employment agencies, in alliance with the state, have stepped in to mount recruitment drives, and to provide specialized training for interactive service work that has some distinctive features, relating to the need for social interaction with users, customers, clients, or consumers and the imperative to serve and satisfy them in India's rapidly expanding consumer economy.

An emerging corpus of studies on work in the high-end service sector in India, such as IT-services, BPOs, and call centres, have emphasized that workers are now socialized into new institutional work cultures and inducted into new forms of work regime. ${ }^{10}$ It is, however, far less recognized that low-end service workers, such as security guards, and hotel, catering, housekeeping and hospitality staff, are also now subjected to formal and systematic training, grooming, and socialization, in a significant break with the past. Such training is in part aimed to achieve attitudinal change and positive work approaches. It is also designed to enable workers to acquire relevant skills for "embodied work" and "emotional labour". These have been noted in the analytical literature on work as the hallmarks of interactive services, "that depend on visible, interactive and embodied exchanges in which the physical shape of bodies, their adornment and workers' emotions matter in workplace performances". II "Affective labour" or the production and manipulation of affect of one's own self and others, as well as corporeal and embodied modes of work, rather than physical or manual toil, are important here.

This paper explores these and similar non-economic aspects of labour management and employment relations that are geared towards reshaping workers' sense of self, and draws attention to the cultural constitution of workers' subjectivity through workplace practices. ${ }^{\mathrm{I2}}$ The impact of these

Io. Carol Upadhya and A.R. Vasavi, "Outposts of the Global Information Economy: Work and Workers in India's Outsourcing Industry", in idem (eds), In an Outpost of the Global Economy: Work and Workers in India's Information Technology Industry (London [etc.], 2008), pp. 22-27; see also Nandini Gooptu, "Neoliberal Subjectivity, Enterprise Culture and New Workplaces: Organized Retail and Shopping Malls in India", Economic and Political Weekly, 44: 22 (2009), pp. 45-54.

I I. Linda McDowell, Working Bodies: Interactive Service Employment and Workplace Identities (Chichester, 2009), p. 6, ch. 3; see also: Robin Leidner, "Emotional Labour in Service Work", The ANNALS of the American Academy of Political and Social Science, 56I (1999), pp. 8I-95; Amy S. Wharton, "The Sociology of Emotional Labour", Annual Review of Sociology, 35 (2009), pp. I47-165. For a pioneering study of emotional labour, see A.R. Hochschild, The Managed Heart: Commercialization of Human Feeling (Berkeley, CA, 1983).

I 2. For analysis of similar processes in the West, see Nikolas Rose, Inventing Our Selves: Psychology, Power and Personhood (Cambridge, 1998), pp. I60-161; idem, Governing the Soul: The Shaping of the Private Self (London, I990), pp. 55-1 I8; Zygmunt Bauman, Work, Consumerism and the New Poor (Buckingham, I998), ch. 4 . 
processes on inequality, social subordination, and class identity are also examined. Finally, the paper analyses how political norms in India's highly mobilized electoral democracy influence workers' perceptions of labour relations, and how, in turn, political subjectivity produced at the workplace has implications for democracy and citizenship. The paper is thus analytically concerned with the mutual constitution of workplace relations and mass politics in post-colonial contexts.

The focus of enquiry in this paper is the private security industry that has experienced a boom in recent years. ${ }^{13}$ It is by far the most important among the newly emerging services. The security sector epitomizes some of the most dramatic changes in the urban employment market and in labour processes, affecting a substantial section of the poor, unskilled workforce in towns and cities. Labour relations here are representative of those in similar new sectors of employment, such as hospitality, housekeeping, catering, and so on.

Research for this paper was done in several stints of fieldwork from 2009 to $20 \mathrm{I} 2$ in the city of Kolkata (formerly Calcutta) in eastern India, where interviews and discussions were conducted with the management and workers of private security companies and training agencies. Detailed and in-depth qualitative research was concentrated on a major security company that supplies guards to numerous important sites in the city, along with its associated training agency that has extensive collaboration and partnership with the government and urban development institutions for the skill development of poor youth. Non-participant observation was undertaken at recruitment camps, training sessions, and at several sites where security guards are deployed, with the opportunity of conversation and discussion with staff taken up whenever possible during their working shifts. Interviews at length were conducted with nearly forty security guards, mostly in the absence of their managers and employers, but usually with the knowledge of management. Most of these workers came from rural and suburban areas or urban slums, and were from a family background of agricultural work, casual labour, and self-employment in the lower reaches of the informal sector, although most were educated to at least high school standard. Anonymity was promised to all workers, to allay any worries about management having access to their views.

\section{RISE OF THE PRIVATE SECURITY INDUSTRY IN INDIA}

According to CAPSI, the national-level Central Association of the Private Security Industry, around I 5,000 security agencies employ 
7 million private security guards in India today, ${ }^{14}$ which is more than the combined strength of the police and the armed forces, and India has more private security personnel than any other country in the world. The industry is acknowledged to be one of the largest and fastest generators of employment in the country, creating up to I million jobs each year, according to some estimates. ${ }^{\text {Is }}$ The importance of the private security system has been acknowledged by the passing of the Private Security Agencies Regulation Act (PSAR Act) in 2005, and is also evident from the presence of various official dignitaries and government ministers at CAPSI's annual meetings, most notably the President of India in 2009, when she was hailed by CAPSI's National Chairman as "Our Supreme Commander", echoing the President's role with respect to the national security forces. ${ }^{16}$

India is not, of course, unique in witnessing the commercialization and commodification of security. The exponential expansion of the private security industry within a "mixed economy of protection" 17 is now a global phenomenon. ${ }^{{ }^{8}}$ The international literature on the private security industry offers two broad lines of interpretation to account for the rapid rise of this sector in the past few decades. The liberal-pluralist approach cites limited state capacity and the complementary role of the state and the private sector in law and order, while the radical political-economy perspective identifies the private security system as the enforcer of an increasingly powerful corporate order of private capital. ${ }^{19}$ Both explanations help to shed light on the Indian scenario in different ways.

I4. Website of CAPSI: http://www.capsi.in/index.html; last accessed 9 April 20 I 2.

I 5. "Trends: Security Services: A Sunrise Industry": http://www.capsi.in/pst.pdf; last accessed 9 April 20I2; website of CAPSI: http://www.capsi.in/index.html; last accessed 9 April 20I2; Sanjay Upadhyaya, "Labour, Employment and Social Security Issues of Security Guards Engaged by Private Security Agencies: A Case Study of Okhla and Noida", NLI Research Studies Series, No 093/20 I , V.V. Giri National Labour Institute, Noida, UP, pp. I०-I I.

16. Security Post, [hereafter, SP], I6 (March-April 2010), cover page. Security Post is the newsletter of CAPSI \& APDI (Association of Private Detective Agencies of India).

I7. This phrase is taken from, Ian Loader, "Private Security and the Demand for Protection in Contemporary Britain", Policing and Society, 7 (1997), pp. I43-162, I 47.

I 8. Ibid., pp. I43-162; Shearing and Stenning, "Modern Private Security", pp. 193-245; Alison Wakefield, Selling Security: The Private Policing of Public Space (Cullompton, 2003); Nigel South, Policing for Profit: The Private Security Sector (London [etc.], 1988); Trevor Jones and Tim Newburn, Private Security and Public Policing (Oxford, I998); Bruce Baker, "Living with Non-State Policing in South Africa: The Issues and Dilemmas", Journal of Modern African Studies, 40 (2002), pp. 29-53; Rita Abrahamsen and Michael C. Williams, "Introduction: The Privatisation and Globalisation of Security in South Africa”, International Relations, 2 I (2007), pp. I3 I-I4I; Teresa Pires do Rio Caldeira, City of Walls: Crime, Segregation and Citizenship in Sao Paulo (Berkeley, CA [etc.], 2000), chs 5, 9.

19. Mark Button, Private Policing (Devon, 2002), pp. 20-32; Shearing and Stenning, "Modern Private Security", pp. 193-245. 
The need for the deployment of private security guards initially arose with the inception of economic reforms and the tendency to downsize the state from the I990s, when various public sector companies and government departments began to outsource security functions. Taking advantage of this, international security companies, such as Group 4, started making inroads into the country, setting in train the professionalization of private security services and the emergence of numerous new agencies within the country. By the early 2000 s, the efficacy of public-private partnership had come to be widely accepted in official circles. Meanwhile, international terrorism, and India's own peculiar vulnerability, escalated a public preoccupation with security and protection, taking precedence over mere maintenance of law and order or crime control. These concerns are reflected in an official inclination for collaboration between the state and private security companies over policing functions.

Government ministers have repeatedly emphasized the surveillance function of private security agencies and their trained guards in the prevention of crime, terrorism, and political violence. At CAPSI's 2009 annual meeting, the Minister of State for Home Affairs pointed out the low ratio of police personnel per capita of the population in India compared to the international norm (India: I.45 per I,000 population; global norm: 2.2 per $\mathrm{I}, 000$ ), and explained that resource constraints prevented the rectification of this woeful inadequacy. He, therefore, welcomed the private security industry as an ally of the police and security forces. ${ }^{20}$ In 2010 , the General Secretary of the ruling Congress Party noted that globally security issues have overshadowed economic ones, which offers a "great business opportunity" for private security agencies. ${ }^{2 I}$

The private security industry has also benefited from an increased official commitment to involving local communities in policing. In recent years, community participation and citizen empowerment have been emphasized as a mark of good governance, along with the shared responsibility of citizens and the government in maintaining security and ensuring protection from crime and violence. A message from the Prime Minister's Office, sent to CAPSI, on the occasion of its annual meeting in December 20I0, states: "Internal security has acquired a new meaning in this age of terror. Ever greater vigilance on the part of security establishments and civil society is the need of the hour. In India we will need to make security a citizens' project." 22

In keeping with this spirit, in the city of Chennai, a high profile police officer has launched the "Friends of the Police" initiative for community involvement, which was inaugurated by the Minister of State for Home

20. SP, i6 (March-April 2010), p. 3.

21. $S P$, ig (January-February $201 \mathrm{I}$ ), p. го.

22. Cited in SP, i9 (January-February 201 I), p. 3. 
Affairs, and which is reported in CAPSI's newsletter to acknowledge that "the security guard is an essential link between the public and police." ${ }^{23}$ In Kolkata, where this research was conducted, the police have undertaken numerous initiatives to engage with citizens. ${ }^{24}$ Notably, the so-called "Green Police" or the Civic Police Volunteer Force has been created in alliance with the municipal corporation, with young, usually unemployed, recruits from local neighbourhoods, who are tasked with monitoring their own community and report on environmental crimes and law-breaking to the police. ${ }^{25}$ Private security guards have been seen as an important component of this overall urban co-policing infrastructure and as a vital source of information on potential crime and terrorism, by virtue of their embeddedness in the community and close contact with the general population on a daily basis in the course of their work, especially in mass private property, which the police do not have the capacity to cover.

The private security industry has also, no doubt, thrived as a consequence of an increased risk and threat perception among some sections of Indians, and their heightened anxiety for protection and security. A Times of India opinion poll, on the eve of Independence Day in 2010, found that a majority of Indians valued security as a key aspect of freedom. They judged the security forces to be a guarantor of their freedom, and were willing to allow an invasion of their own privacy in the interest of enhancement of security. ${ }^{26}$ This preoccupation with security is particularly prominent among India's urban-based upper and middle classes, not only due to rising political violence, the increasing strength of the Maoist Naxalite movement, and the fear of terrorism, but also on account of an accentuated perception of political threat from below, verging on "demophobia", in the context of the growing mass democratic mobilization of the poor and lower castes since the $1990{ }^{27}$

As a result, Indian elites and middle classes have welcomed the deployment of private security guards at all manner of public and private sites that, unless properly guarded, are considered prone to the incursion of the lower orders, not to mention being potential terrorist targets.

23. SP, i6 (March-April 2010), p. 4.

24. Several instances of community policing and citizen engagement are cited in Kolkata Cops: The Kolkata Police Blog, Is November 2010, available at: http://www.kolkatacops.com/ kolkata-cop/kolkata-cop-2/; last accessed 9 April 2012.

25. "Green Cops for Clean Calcutta", The Telegraph (Kolkata), 3 August 2008; "Green Police for Neighbourhood Vigil", Times of India, 3 August 2008.

26. Times of India, is August 2010.

27. Leela Fernandes, India's New Middle Class: Democratic Politics in an era of Economic Reform (Minneapolis, MN [etc.], 2006), pp. 176-189; Nandini Gooptu, "Economic Liberalization, Urban Politics and the Poor", in Sanjay Ruparelia et al. (eds), Understanding India's New Political Economy: A Great Transformation? (London [etc.], 20I I), pp. 35-48, 40-42. 
Guarding of such private sites is beyond the capacity of the police, or indeed beyond their expected function. Private security services have effectively stepped into this breach, with an emphasis on preventive patrolling, intelligence gathering, and surveillance, rather than armed protection. Thus, Indian cities do not have fortified enclaves with armed guards as in Latin America, but uniformed security guards, usually without firearms, are now a ubiquitous presence in the city. A citizen is likely to encounter them at almost every site visited during a normal day, including offices, schools and colleges, housing complexes, shops, banks, entertainment venues, sports grounds, hospitals, airports, railway stations, subway systems, and so on.

By far the most important boost to the private security industry has come from the rapid growth of the private corporate sector in India in the past couple of decades in an era of ascendant corporate capitalism. Private firms and companies, and owners and managers of mass private property, require the safeguard of their economic interests through the protection of their assets and property, and the surveillance and monitoring of their staff, employees, clients, and consumers alike. Security guards as uniformed personnel, embodying discipline and order, are also deployed as front-line staff to meet and greet corporate clients and customers, thus helping to project an image of professional efficiency and safe reliability. Corporate firms prefer to use private security, rather than relying on the police, even if the state policing system were to have adequate capacity. This is because technological provision and human resource input supplied by private security companies can be specifically tailored and dedicated to the maintenance and defence of the interests of corporate capital, unlike the public system of law and order. The Confederation of Indian Industry (CII) has, therefore, invited CAPSI member companies to join the organization. Both $\mathrm{CII}$ and the Federation of Indian Chambers of Commerce and Industry organize and host regular meetings and conferences with CAPSI and work closely with it on risk and security matters. ${ }^{28}$

\section{RECRUITMENT OF LABOUR}

With the rising demand for security services, private firms have taken on the task of supplying trained staff. Able-bodied young people, in their twenties and thirties, are required for security jobs, with at least school-leaving educational qualifications. These firms often ally with NGOs and other private agencies that offer government-sponsored skill development and vocational training schemes. Workers are sought from rural, peri-urban, and suburban areas as well as urban slums, by organizing recruitment camps and job fairs. Initial information is disseminated through leaflets, posters, 
and loudspeakers on rickshaws or motor cycles. These are followed by induction sessions and meetings at local council offices and communitybased organizations. Here prospective workers are first collectively counselled at meetings and then vetted individually, as far as possible.

"Counselling", a term used by recruiters themselves, entails explaining the nature of the job, its rewards, and its relevance in affording entry into the putatively lucrative private corporate labour market. At these sessions, and during subsequent formal training, security work is compared with the army and the police who protect citizens and fight for the country. It is argued that private guards too protect the public, while, at the same time, they engage in the struggle to support their own families, which is a particular kind of worthy fight - that for a better life. The respectability and attraction of the work of guarding is dilated upon with reference to the history of exalted private royal guards in ancient and medieval India, as well as by analogy with private detective work, which carries a certain cachet of glamour. Recruiters emphasize that security guards are not private or personal servants, but are trained professionals, placed in corporate organizations, who work with modern security techniques and technologies. Care is taken to distinguish traditional businesses or labour contractors from security firms as new style employment agencies and professional enterprises that offer steady jobs and attractive career prospects.

These jobs are projected as a form of corporate citizenship, or a mode of enfranchizement in the private corporate economy that guarantees upward mobility. Examples are cited of individuals from deprived rural or slum origin with limited education, who have become security guards and succeeded in owning their own homes and two-wheeler vehicles and in sending their children to good academic institutions. It is also, however, explained that it is necessary not to aim too high, and to get an initial foothold on the lowest rung of the job market and the corporate economy, commensurate with one's limited educational and other qualifications, and to relinquish any unrealistic ambition for office work or well remunerated employment. No job should be considered too low or undesirable in today's over-crowded and challenging labour market, it is stressed, as long as it provides an honourable source of livelihood. Moreover, unfailing commitment and uncomplaining, conscientious hard work are required for promotion and progress in corporate sector service jobs, that are both highly competitive and scarce, being chased by many eligible and well qualified contenders.

The purpose of this kind of contradictory "counselling", which raises aspirations about a rosy future while also reining in ambition and striking terror about the vicissitudes of the labour market, is to ensure the tenacious and sustained labour market participation of poor youth in low-level jobs, even when faced with unrewarding and exploitative work. For the same reason, prospective recruits are also vetted through 
interviews, and also often through home visits and discussion with the family, to ascertain the level of "motivation" of the recruit and the extent of their "need" for a job, as explained by recruiters.

In their recruitment drives, these firms frequently receive the assistance of the local government, such as panchayats (village councils), urban local bodies, and the district administration, who help to organize camps and disseminate information. Local councillors also help to identify prospective recruits and provide them with certificates to confirm the absence of any criminal history and to vouch for their character. These politicians find it advantageous to be involved in the process of recruitment as a welcome opportunity to act as patrons of their job-seeking local constituents. More importantly, local councils and various government departments are willing to enter into institutional partnership with private recruitment and training organizations, in line with the government's stated commitment to tackle the significant problem of unemployment among low-skilled, poor youth. State agencies often bear the cost of the skill development of unemployed youth, who are offered free training.

The central government's Directorate General of Employment and Training (DGET), under the Ministry of Labour and Employment, initiated, in 2005-2006, a programme of skill development for the informal sector, based on imparting "modular employable skills" through short courses based on fixed curricula. Under this scheme to enhance employability, a course syllabus and a training programme for security guards were devised in discussion with corporate interests. While DGET finances the training, private agencies are responsible for actual course delivery, under the private-public partnership framework. The course is approved and accredited by the National Council for Vocational Training that issues certificates to candidates on successful completion. Since 2008, the Indira Gandhi National Open University (IGNOU) has been running short-term training courses for private security personnel, to turn out "regimented, disciplined and trained professionals", in collaboration with the Security Skills Council of India (SSCI), which is a private entity and a subsidiary unit of SIS, one of India's long-established and largest national security firms. ${ }^{29}$

More recently, the Indian government's high-profile National Skill Development Policy of 2009 has mandated that Sector Skill Councils would be constituted with private sector involvement, with the aim of funding and setting up vocational training centres to help produce 500 million skilled workers by 2022 for specific sectors of employment. To take this forward, the Security Knowledge and Skills Development Council was launched by the National Skill Development Corporation, in

29. IGNOU-SSCI Courses: Special Features: http://www.ssci.co.in/SecurityQualification.aspx; last accessed I8 April 2012. 
alliance with CAPSI, in December 2010.30 With extensive funding and support forthcoming from government sources in these ways, training and recruiting security guards, and indeed workers for similar jobs has increasingly emerged as a highly profitable enterprise for various private agencies.

Through these collaborative employment and training schemes for the security sector and similar other low-skilled work, the government aims to target the following: (a) "Below Poverty Line" and other "backward" youth, including women, low castes, and tribal groups; (b) "under-developed" regions and neighbourhoods within and outside towns and cities where employment opportunities are low; and (c) areas that are prone to political unrest. SIS and SSCI, as well as CAPSI, for instance, have recruited and trained youth from rural areas, especially lower castes and tribals, with funding and assistance from the governments of Orissa and Jharkhand, these states being known for areas of acute economic deprivation and for radical left-wing politics. ${ }^{3 \mathrm{I}}$ The State Urban Development Authority of the province of West Bengal, of which Kolkata is the capital, has also linked up with training agencies to recruit youth from areas of political violence. A former Governor of the regional state of Mizoram in India's insurgency-affected north-eastern hilly areas, is reported to have urged CAPSI to "generate more jobs to check insurgency". ${ }^{32}$ Unemployed, unskilled poor youth are intended to be weaned away from political violence and extremism through the provision of work in cities. ${ }^{33}$

The process of training these youths from politically unsettled areas requires a particular emphasis on pacification, character reform, and mental and physical discipline, because the potential, or even actual, agents of political unrest are now deployed to guard the corporate economy and the established social and political order. This raises a question about the wisdom of recruiting from these sections of society, but as recruiters have explained, no-one but the most economically distressed and the least educated would easily respond to recruitment for urban low-level jobs. Those with some education and economic staying power have aspirations to better jobs, and they would not enter the lowest end of the labour market unless compelled by circumstances. Security companies have, therefore, found it judicious to ally with the government to recruit from the poorest classes and most underdeveloped areas, including those drawn into the fold of militant politics out of economic distress. It is also believed by security firms, rightly or wrongly, that

30. SP, I9 (January-February 2011), pp. 28, 32-34.

31. SSCI: About Us: http://www.ssci.co.in/aboutus.aspx; last accessed i8 April 2012; SP, I9 (January-February 20I I), p. 33.

32. SP, I9 (January-February $20 \mathrm{II}$ ), p. $2 \mathrm{I}$.

33. SP, I6 (March-April 2010), p. 8. 
youths from poor backgrounds are likely to be meek and pliable, being desperate to earn a living.

Evidently then, a formalized, structured, and institutionalized system has gradually taken shape to recruit and train labour from most deprived and vulnerable social groups and regions. While in this way various government initiatives have been designed with private security firms to tackle the problems of unemployment, poverty, and political unrest, yet importantly, the state is also subsidising private firms and the urban private corporate sector in this process to meet the costs of the recruitment, training, and vetting of security staff. This is helping to solve what many consider one of India's major human resource problems - that of the supply of trained and disciplined labour to service the lowest end of the urban corporate economy. The "Introduction" to DGET's security staff training course clearly documents this approach:

With [the] economy of India growing like never before and [...] with increasing demand for specialized security personnel in industry, business undertakings as well as at private level, there is a need of an established system for providing training to the unemployed youth, grooming them to take up jobs in security sector. Such trained youth can fill in the void that is present in our system. [...] This initiative [of] providing training [...] will also help in improving the workings and standards of the security agencies hiring such trainees. ${ }^{34}$

\section{TRAINING THE WORKER}

The PSAR Act sets out some key requirements for the training of security guards. Firms registered under the Act, therefore, provide training at various levels, ranging from fairly basic on-the-job training to quite elaborate residential courses. Unregistered firms too increasingly offer some training to make inroads into a market where "professional" staff are now demanded. The syllabus of the DGET, and others derived from it, are normally used, especially by those security and training agencies that work in partnership with local bodies and government institutions and receive state funding for training. Some large security firms follow their own courses and offer independent certificates. According to DGET, training is expected to be conducted: (a) in classrooms, with lectures, discussions, interactive role-play methods, and the use of audio-visual aids; (b) at residential centres or outdoor facilities; (c) at employment sites for "on-the-job" training. Trainers range from retired, usually male, police and military officers to career counsellors and personality development and soft-skills tutors, who are often

34. "Course Curricula for Short Term Courses Based on Modular Employable Skills (MES) in Security Sector", Directorate General of Employment and Training, Ministry of Employment and Labour, Government of India, [hereafter, DGET course], n.d., p. 2. Available from the DGET website: http://dget.gov.in/mes/index.htm; last accessed I8 April 2012. 


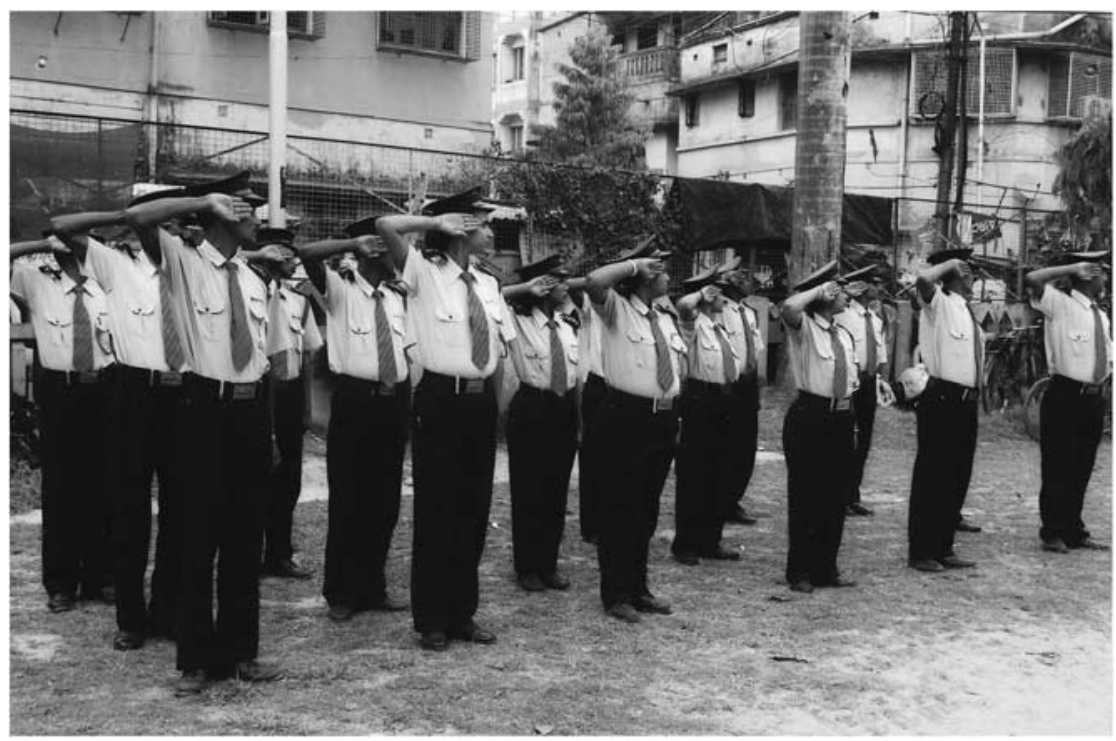

Figure I. Guards learning how to drill and salute.

Keertika Academy, Kolkata. Used with permission.

female. Some key features can be discerned in training schemes across the industry, even where minimal training is offered.

Trainees are given instruction on their duties and responsibilities, on various kinds of risk and threat, and on different procedures and tasks that they will be expected to perform. They receive information on equipment and various aspects of the law relevant to security work. "The focus of the programme is on 'performing' and not 'knowing'", 35 and training is geared to the efficient execution of a set of fixed and routinized tasks, such as searching and checking; locking and securing; detecting unusual objects, people or activity; emergency procedures; fire-fighting; etc. The watchwords of training are protection and safety, but the need to guard corporate interests is also strongly communicated to trainees. This duty includes not only public safety and security as envisaged in policing work, but also comprises, for instance, deterring sabotage or theft of corporate property, and detecting and preventing undesirable or disruptive behaviour on the part of staff and clients that might harm corporate interests.

A major component of training is related to the body and corporeal aspects of a worker's performance, as distinct from manual labour. Control of the body and physical training are considered vital for a 


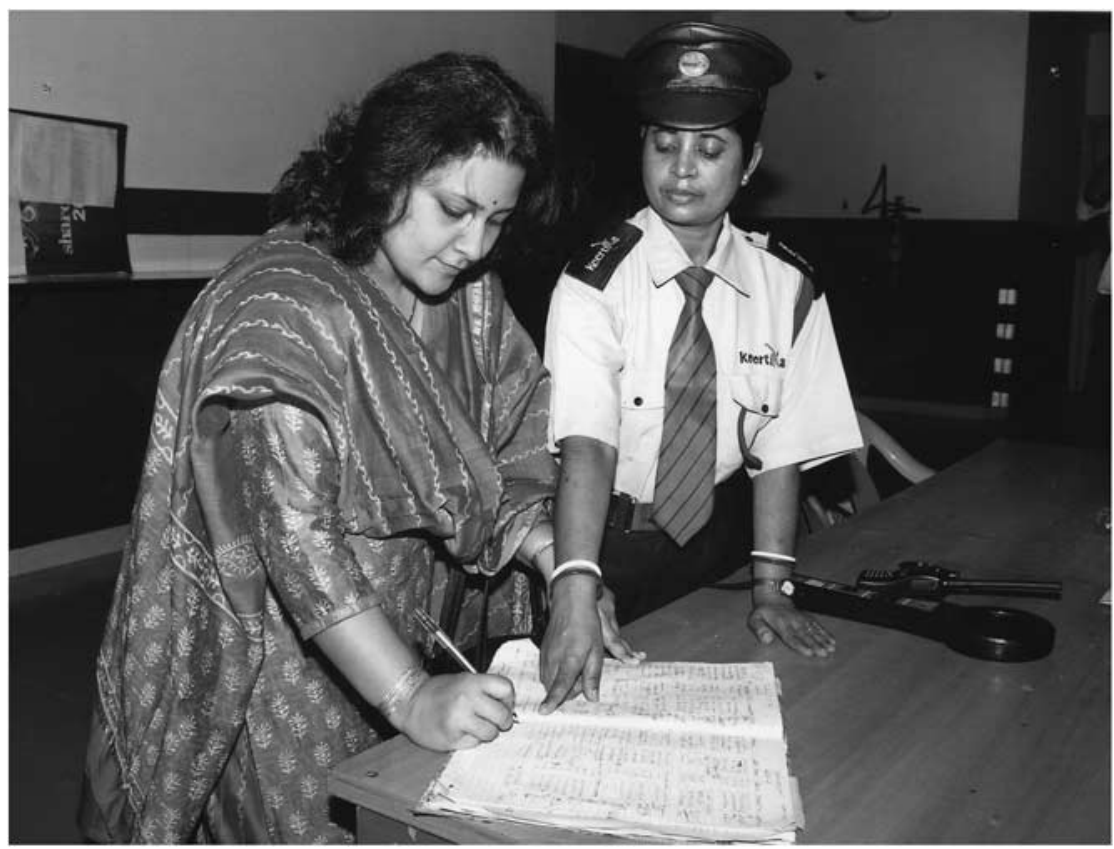

Figure 2. Interaction with customers: a key function of security guards. Keertika Academy, Kolkata. Used with permission.

security guard's work, not only to enhance fitness, stamina, and endurance, but more importantly as an embodied expression of regimented discipline. This is taught through outdoor activities, including drills, marches, and physical exercise, which continue to be conducted at many worksites after training is completed, depending on the availability of space. Thus, in one case for instance, at the start of every shift, the guards were assembled for a brief drill on the car park, after which they were given an update on the day's security requirements and the details of their posting. "Proper wearing of dress", meaning uniform, is also of central importance as a marker of disciplined orderliness.

The term "smartness" is ubiquitously and repeatedly used in all training, for a well-attired and tidy appearance is taken to be the corporeal representation of a set of dispositions and character traits: being alert, prompt, and efficient; being quick on the uptake; having drive and initiative; and being ready to take and execute orders with alacrity. In relation to the notion of "smart" response to orders, the motto that "the client is god" and must be obeyed unfailingly is much repeated, for the client pays the wages. The client here is the firm or the company to which the placement and recruitment agency supplies security guards on contract. "Saluting/greeting" and "proper body movement" are also specifically included in the course syllabus, and are 
designed to make the security guard physically acceptable, non-threatening, and subservient to clients and customers.

In the police and armed forces of the state, saluting signifies mutual recognition by the members of a force and the acknowledgement of rank in a structured hierarchy of service positions. Saluting in security jobs, in contrast, is envisaged as an expression of a security guard's deference and servility to his or her corporate boss, clients, and customers. Rather more than a strong, muscular physique, usually associated with protection and guarding, here visually pleasing, "smart" bodies in a submissive and compliant mode are required. Saluting and related forms of subservient physical gestures also affirm a security guard's low social station and menial work, consonant with existing status, caste, and class hierarchy. In addition, trainees are taught to address all persons of higher social status with the honorific "Sir" or "Ma'am" as a mark of recognition of social superiority and to signify their own subordinate position. While all this is expressed in an apparently "modern" language of professional training, these are also clearly laden with resonances of subservient, deferential, and servile master-servant relationships of domestic work, and they bear the mark of hierarchical caste-based forms of duty and service owed by the lower orders to the higher orders. ${ }^{36}$

Grooming, physical posture, and appearance are also at the heart of training, including polite speech, courteous body language and gestures, good manners, making eye contact when speaking, effective communication techniques and listening skills, as well as acquiring some limited linguistic skills in English, such as key words and phrases for greeting and verbal exchange with customers and clients when conducting routine security tasks. Trainers emphasize that the image of a corporate organization depends on the public face presented by the guards, who are often the first point of contact for customers and clients. The workers are thus tasked with the responsibility of personifying and embodying a suitable corporate ethos, conveying a welcoming outlook and a sense of readiness to oblige, which is considered so central to customer relations in the consumer economy.

Having recruited security staff from poor and "backward" backgrounds, and often from remote deprived rural areas, it poses a challenge to trainers to transform the appearance and speech of staff to prevent them from seeming uncivilized, uncultured, rude, boorish, or rustic. Thus, speech, conduct, gait, deportment, clothing, and makeup for women are all central to training, in order to help develop a presentable persona that would be acceptable to clients and customers and fit in with their sensibility, tastes, and preferences. Since security workers often come into

36. Kathinka Frøystad, "Master-Servant Relations and the Domestic Reproduction of Caste in Northern India”, Ethnos: Journal of Anthropology, 68 (2003), pp. 73-94; Sara Dickey, "Permeable Homes: Domestic Service, Household Space, and the Vulnerability of Class Boundaries in Urban India", American Ethnologist, 27 (2000), pp. 462-489. 
bodily contact or close physical proximity with customers in the course of searching or frisking, the issue of personal hygiene and cleanliness, particularly suppressing bodily odour, is an additional requirement, in order to ensure that no olfactory offence is caused to the customer.

Training of guards also encompasses forms of emotional labour. The DGET training curriculum, for security and other similar service work, at the very outset, highlights the transformation of mental "attitudes" as the key goal of training:

Possession of proper attitudes is one of the most important attribute of a competent person. Without proper attitudes, the performance of a person gets adversely affected. Hence, systematic efforts will be made to develop attitudes during the training programme. [...] Positive attitudes have to be developed in the trainees by properly guiding them $[\ldots]{ }^{37}$

A DGET official confirmed during an interview that "attitude building" was the "topmost priority", and that it is first necessary to "manage the human being" by displacing workers' "old value systems" about work, and changing their bad "habits" to good "instincts".

The list of "core competencies" in the DGET syllabus thus includes a number of items relating to mental attitude, "soft skills", and personality development. Trainees are required to develop both the personal or individual skills of self-management and the interpersonal or interactive skills of dealing with others. Personal skills include "managing stress and aggression; punctuality, discipline, and honesty; respect for rules and regulations; responsibility and accountability; learn[ing] continuously; multi-tasking capacity". Interpersonal skills include "avoiding conflict and reducing risks; cordial relationship, coordination and team work; communication skills". ${ }^{38}$

Much of the above is derived from standard human resource management practices for imparting soft-skills training. However, when applied to lower-level workers like security guards, these assume a specific orientation of inculcating deference, discipline, and docility. Workers are, first and foremost, trained to mould and manage their own personalities, by imbibing the right kind of motivation and the will to work hard, with tenacity and commitment. An aspirational mindset to attain a better life, a robust work ethic, and self-belief are emphasized throughout the training process as the necessary preconditions for individuals to succeed at work in what is depicted as an increasingly complex economy and a demanding labour market. Motivational films are also sometimes shown to trainees that portray tales of the individual achievements and personal heroism of ordinary people, who attain success in the face of adversity by dint of sheer effort and mental conviction. 
Workers are advised to develop initiative and efficiency, but eschew any urge to express inappropriate levels of assertiveness in relation to clients and customers, not to mention a confrontational or adversarial attitude, which might earn them the reputation of being trouble-makers and render them unemployable. They must obey instructions, conscientiously follow rules and regulations, and be ever willing to serve and please, avoiding friction or conflict. All the above together is bundled as "positive attitudes" that every worker must strive to develop. It is, however, also believed that this kind of work causes mental "stress" or "pressure", and hence, much emphasis is also placed on controlling one's own emotions and developing the skills of self-control and self-management, in order to minimize anger, frustration, disillusionment, and lack of motivation.

The remoulding of the mentality, personality, demeanour, and appearance of workers in these various ways is underpinned by the notion of the unacceptability and inferiority of the extant persona of the worker. While being advised to nurture any pre-existing submissive tendencies, they are exhorted to transform themselves in other ways to conform to upper- and middle-class norms and prejudices. Such conformity, it is explained during training, should improve workers' life chances and economic and social mobility. Grooming, makeovers, and personality development are held up as the new tools of upward mobility, and therefore, a central focus of the workers' skill-acquisition programme. Trainees are expected to learn to efface their own identities and personalities and acquire an acceptable image, by rendering themselves likeable and pleasant. Security workers often report their satisfaction at their own makeover, although not usually because they feel their appearance or attitude conform to the predilections of polite society, but because they associate their newly polished image with the glamour and culture of films and fashion. Nevertheless, this kind of civilizing mission constitutes an alienating and confusing experience for them. Even while they consider this a desirable form of personal transformation and a useful employment asset, it is also evident to them that it marks a negation, even condemnation, of their existing identity, personality, and conduct.

When workers are asked to recount their training process, a large majority mentions grooming and makeover and their own change of status perception and self-awareness. They enumerate the key qualities of a security guard usually as smartness, implying both a well-turned-out appearance and a keen and efficient approach to work; willingness to work hard and stretch oneself mentally and physically to the utmost; self-control; patience to endure insults (on which more below); obedience; and the capacity to conform and accept prevailing conditions without questioning. Most of these evidently refer to personality traits and emotional or behavioural qualities. Moreover, such characteristics as courage and physical strength, that might be associated with guarding, protection, or policing work, are 
here conspicuous by their absence. The emphasis on bodily performance and emotional labour in the training process clearly has a significant impact. Systematic training for embodied work and emotional labour of this kind is a new feature of work in low-end interactive services in India's private corporate sector.

\section{EXPERIENCE AT WORK}

While the process of recruitment, training, and skill development of poor and deprived youth is state subsidized and approved, the involvement of state agencies ceases once workers enter employment, giving employers free sway to exploit labour as they choose, with employment relations at the workplace and working conditions being largely unregulated. Moreover, cultural intervention to reshape workers' sense of self, in line with contemporary human resource management practices, as seen above, come to be supplemented with far more direct and overt forms of control and coercion associated with customary forms of social subordination and older strategies of labour deployment. Having been delivered to the bottom of the private corporate economy through a state-aided organized process, and having been enticed with the promise of mobility and advancement in the "modern" sector of the economy, these workers are left with little more than low-paid, insecure employment, no state protection, negligible realistic possibility of upward mobility within the security sector, and only the alternative option of courting unemployment or making a lateral exit to other similar jobs at the lowest end of the labour market.

The vast majority of security staff is not directly employed by any corporate organization, in order to minimize employment costs by outsourcing and using labour on a contractual basis from security agencies. These agencies recruit guards and place them at various sites, in return for which the security firms receive payment from the purchasers of their service, from which the wages of the guards are paid and the firms' profits are generated. Guards are frequently transferred from one site to another, in response to different clients' changing needs. There is little or no effective protection of workers' rights or regulation of employment relations by the state. Although the PSAR Act requires the implementation of labour laws, there is no mechanism of enforcement. Low rates of pay, long hours of work, arbitrary dismissal, lack of leave or holiday entitlements with a "no-work-no-pay" regime, and absence of accident benefit, were all mentioned by workers during interviews and discussions for this research, and are consistent with the findings from surveys of the working conditions of security guards elsewhere in India. ${ }^{39}$

39. Upadhyaya, "Labour, Employment", chs 6, 7. 
Work is physically arduous, often with "standing duty" for long periods, causing trepidation among workers about early physical burn-out. Working hours are extremely long, with overtime work being undertaken by most to augment their paltry wages. Most claimed that their wages were too low to sustain a family properly, to send children to school, or to meet any health costs. In the absence of suitable accommodation near workplaces, travel time to and from work and commuting expenses further increased the actual time devoted to work and reduced the take-home pay, not to mention impairing family and community life.

With regard to social security, those employed by the bigger and more organized firms enjoy the benefits of the Provident Fund Scheme for Pensions (PF) and the Employees State Insurance (ESI) system for health and medical cover. However, these exist largely as paper benefits that recruitment agencies or employers find useful to offer in order to meet the terms of the PSAR Act, but most workers consider ESI and PF deductions as a form of imposed levy and a reduction of their already extremely meagre salary. Few workers understand the workings of PF and ESI, because they are seldom given sufficient information or briefing to help access these benefits. With high attrition rates and frequent change of employment from one firm to another in the security industry, workers usually forfeit their PF money. In theory, workers can apply for their Provident Fund benefits to be transferred to their new employment, but this requires the assistance of their employers, who consider the administrative costs of dealing with PF in this way too high.

Within this context of exploitative employment relations, workplace discipline is stringently enforced to ensure compliance and to deter any expression of discontent. Electronic surveillance and various other methods are pressed into action to monitor the daily work of guards and their conduct and behaviour. The head of security of a major privately owned leisure and retail venue stated that he would deliberately drop a currency note or a wallet with money to tempt workers to see if anyone fell into this trap. He would also keep an eye on CCTV and observe the interaction of security staff with customers. If anyone was seen to be rude or not sufficiently obsequious or neglecting their duty, s/he would be summoned on an "office call" to be reprimanded, "brain-washed", or even threatened with dismissal. Workers can be summarily dismissed on disciplinary grounds. Fines and pay deductions are also widely prevalent if, for instance, goods go missing during a guard's shift, on the assumption that the theft was caused by the guard's dereliction of duty. In multiplex cinemas, guards are required to prevent viewers from taking water bottles, betel nuts for chewing, and any food into the auditorium, but if a member of the audience is subsequently found with these items inside the hall, the guards on duty are forced to pay a fine for their purported negligence.

Security guards themselves identify these measures of discipline and control as some of the most important factors that render their work 
highly stressful and breed a sense of insecurity and injustice in the face of arbitrary use of power. One guard commented that this was no better than the lot of daily casual labourers in the informal sector, even though the latter were supposed to receive far worse treatment than those working within the corporate sector.

Under these circumstances, workers might be expected to protest or engage in collective action. Some attempts had been made in Kolkata by employees of some security firms to organize themselves, but this was swiftly nipped in the bud with the immediate dismissal of any worker involved with unions. To prevent any future unionization, workers are subjected to regular transfers and electronic surveillance. They are played off against each other to report on any overtly disgruntled colleague. Teamwork is pragmatically encouraged for the efficient execution of duties, but any evidence of fraternal bonding is seen as a threatening trigger of collective action and solidarity against employers. Thus, workers coming from the same area or neighbourhood and those who are known to be friendly are usually not posted in close proximity.

Apart from employers' strategies to prevent dissent or collective action, in a number of cases, young workers were themselves either oblivious of labour rights or they did not regard these to be accepted norms in the labour market that can be legitimately invoked. Indeed, many found it surprising that they were asked in such detail about seemingly irrelevant and inconsequential labour rights, workplace entitlements, or trade unionism during interviews for this research. Most consider workplace agitation directed at employers or the state to be futile and counterproductive, leading to dismissal, and worse still, prone to opportunistic politicization by politicians, which ultimately harms the workers' cause. Moreover, a majority of workers are used to worse conditions, having come from poor, labouring backgrounds. Many stated that working as a security guard, no matter how demanding, was far better than back-breaking, agricultural labour, often in extreme weather conditions.

Those who have previous personal or family experience of working in factories, were unequivocal that security work, even though extremely onerous and mentally stressful, was still preferable to the noise and pollution of mills and the physical exhaustion and frenetic pace of work to keep up with machines. According to many workers, working in a uniformed service and in "respectable" urban work sites in the city was considered to be of higher status in their local community than rural farm work or urban casual unskilled manual wage labour or domestic service. Several security guards commented that unlike their parents, who were not literate, they had worked hard to gain some educational qualifications, even if only school-level studies, and they therefore aspired to nonmanual jobs as well as "service" in private companies instead of domestic work. Some expressed an interest in business, but dismissed that as a 
feasible option due to the lack of capital and the vagaries of petty trade or production, and opted for paid employment instead.

Not surprisingly, workers have a contradictory and ambiguous attitude to their work. Despite the problems in workplace relations and conditions of work, they themselves do not consider these to be the main source of their grievance or discontent, for the reasons cited above. They are far more exercised by what they see as the "lack of a future" and lack of self-worth, as well as "lack of respect". Some claim that they are doing "public service", akin to police or army work, by ensuring public safety and security through their vigilant watch and ward functions. In mass private property, they also seek to take pride in their work at the frontline of emergency services, being responsible for initial fire-fighting and rescue work in case of any accidents. However, most of them also recognize that their work has little to do with public service and that they are, in fact, working for private "bosses" and protecting their interests. Moreover, they feel their contribution is largely overlooked because they are not part of the corporate workforce, being deployed on a contractual basis.

Workers are therefore unable to develop a desirable occupational identity or a sense of self-worth, while also feeling marginalized and disenfranchized in the private corporate economy. This sense of exclusion is reinforced by the perceived problem and fear of "lack of a future". While a handful of workers thought that they could rise up the labour hierarchy to supervisory positions, or diversify into other specialist services within the broad market for security work, or move laterally into other more lucrative segments of the consumer economy, most felt they had no opportunity of upward mobility in the security sector and could not visualize a clear path of future progression in related or ancillary fields. They were well aware that the private security industry had an informal age bar, with workers most unlikely to be retained in their forties, even if someone chose to stay the course for that long. Having entered the seemingly promising and expanding private corporate sector, and with aspirations for mobility, most felt that other than preventing unemployment, they had not improved their life chances or future employment opportunities. Literally and metaphorically, the guards are left standing at the gate of the corporate economy in a condition of endemic insecurity and immobility, and denied corporate citizenship.

Above all, almost every person drew attention to the "lack of respect" as the overwhelmingly important feature of their work that they found most difficult to accept. The vernacular term "opoman", meaning humiliation or insult, was repeatedly used. All workers either bemoan or vent anger and outrage at the daily experience of humiliation and contemptuous and demeaning behaviour meted out to them by customers and clients. Workers claim that they are treated like dirt and, although they wear uniforms and perform similar duties as the police, they are not treated with comparable respect. This sense of degradation and diminution is particularly acute 
among those who came to private security work having failed to join the police or the army or other government services. One worker commented that she had told her family members that she was working with Kolkata's Green Police, because that force enjoyed legitimacy, respect, and recognition, having been set up by the government, even though it was not formally a part of the police force. In contrast, working as a private security guard, despite its new professional trappings and the veneer of grooming, was still no better than being a mere domestic or personal servant at the beck and call of the upper classes, who treated them with utter disdain and even hatred. Many had chosen security work mainly to avoid the humiliation of private domestic work, only to find themselves in a situation of personal subordination.

One worker recounted regular encounters with customers who suspect that guards might steal a purse or a wallet or other valuables while searching bags, and hurl verbal abuse at them for being dishonest, uncivilized, and worthless. The workers' distress is worsened by being forced to maintain a servile bodily posture and demeanour and mental deference, while having to endure relentless indignity with patience. One commented, "We have to learn to make ourselves low [i.e. debase ourselves] and meekly digest all that is thrown at us". Many felt that they were treated almost like animals or as untouchables, and one guard commented that this job had given her insight into the true nature and vile character of supposedly genteel and civilized urban people. Some of them also asserted that no-one would dare to belittle them in this way in the countryside, which is a plausible claim in view of the widely acknowledged fact that rural dominant classes now have to temper their expression of power and status because of the expansion of local democracy and the increasing awareness of rights among subaltern classes.

In contrast to the violation of employment rights, it is their daily humiliation that workers find most difficult to cope with. As a consequence, the perceived key contradiction that has emerged in these service jobs is not one between employers and employees, but between service workers and customers and clients, who come broadly from the upper and middle classes. This has sharpened antagonistic social identities and created or accentuated a sense of being at the bottom of an unequal hierarchy as the new exploited and hated underclass. This sense is no doubt further fuelled by the sharp and visible disparity of wealth and privilege evident at places of corporate business and at sites of middle- and upper-class consumption where the guards work. One security guard noted angrily, "customers and clients think that they have bought our heads and can say what they like, just because they have money".

Here purchasing power and the power to invest are identified as marking out a fundamental social cleavage in India's consumer and entrepreneurial economy. At the same time, this challenges what is seen as 
the attempts of the moneyed classes to enslave and assert proprietary control over those whom they consider socially subordinate. Humiliation here, however, also resonates with pre-existing forms of service work in the informal sector and in domestic services. On this subject, the political scientist Bhikhu Parekh remarks, "Humiliation involves violating an individual's self-respect and demeaning or belittling her in her own and/or others' eyes. Organized or institutionalized humiliation exists when social institutions and practices embody disrespect for, and systematically violate the self-respect of, groups of individuals." ${ }^{\circ}$

Such a regime of humiliation in informal work and in everyday social relations is historically and culturally associated in India mainly with the social institution of caste. Now, analogous forms of humiliation are being reproduced in the interactive services in new workplaces, with the organized, systematic inculcation of new work cultures of deference and servility, as well as the quotidian routinization and institutionalization of humiliating encounters. Although the regime of bodily servility and personal submissiveness in interactive service work is not related to caste, yet, by analogy, these could be seen by workers to lay the foundations of a new secular caste system of servile labour at the base of the economy. This engenders an acute sense of subordination, especially in a wider social and political context where caste-based domination and exploitation are now considered illegitimate, with an assertion of the rights of the lower castes and a more general "democratic upsurge" among India's poor and low caste population. ${ }^{4 \mathrm{I}}$

One worker, for instance, expressed his incredulity and indignation that "free" human beings of a democratic country could be treated in such contemptuous and insulting ways with impunity. Others similarly invoked democratic notions of freedom, equality, and justice to question humiliation and what they saw as the violation of citizens' rights. A democratic political idiom, rather than concepts of workers' rights, thus provides the language to challenge the myth of corporate citizenship that is offered through the promise of lucrative employment.

Despite the above, workers appear to have learned to cope with their predicament, partly because of the formidable constraints on venting

40. Bhikhu Parekh, "Logic of Humiliation", in Gopal Guru (ed.), Humiliation: Claims and Context (New Delhi [etc.], 2009), pp. 23-40, 3I.

4I. Javed Alam, "Is Caste Appeal Casteism?: Oppressed Castes in Politics", Economic and Political Weekly, 34 (1999), pp. 757-76r; Javeed Alam, "What Is Happening Inside Indian Democracy?", in Rajendra Vora and Suhas Palshikar (eds), Indian Democracy: Meanings and Practices (New Delhi, 2004), pp. 79-98; Yogendra Yadav, "Understanding the Second Democratic Upsurge: Trends of Bahujan Participation in Electoral Politics in the 1990s", in Francine R. Frankel et al. (eds), Transforming India: Social and Political Dynamics of Democracy (New Delhi, 2000), pp. I20-145. 
discontent, and partly due to the hire-and-fire regime that acts as an "insecurity-inducing strategy", ${ }^{42}$ by maintaining an ever-present threat of unemployment. Most importantly, "counselling" plays a part in fostering a mindset of conformity, and asserts a pastoral form of power over workers. Both during training, and in the course of work, "counselling" is considered by trainers, managers, and supervisors to be of utmost importance, to help boost morale and sustain the motivation to work. Counselling is aimed at enabling workers to adapt to their work environment by guiding them to develop their own determination to stay in employment against all the odds, as well as to fortify their strength of will. Although projected as a welfare measure in a pastoral mould, counselling serves as a means of efficient extraction of labour by containing disruptive disgruntled behaviour or expressions of discontent, and as a subtle method of persuasion to ensure that workers accept existing conditions.

Some workers did indeed view counselling as beneficial, and conducive to creating a supportive and congenial work environment, with supervisors and managers acting as mentors and advisors. Importantly, however, interpretation and representation of workplace conditions as "stress", and the consequent emphasis on personal mental coping skills, discourage any interrogation of workplace contradictions, and encourage workers to internalize and psychologize the problems at work and fall back on individualized, privatized emotional solutions. Thus, for instance, one security guard explained that, having lost his previous job by protesting against bad working conditions, he had now joined another security firm and taken recourse to spiritualism and meditation to rise above his daily grind and endure the tribulations of work. Speaking of colleagues who have left the security sector, workers do not directly blame the exploitation that may have driven their co-workers out of their job, but describe them as people who could not stomach daily humiliation or failed to cope with, or bear the pressures of, strenuous work or the stress of being incessantly disciplined and monitored. The emphasis here was on personal failure rather than structural exploitation.

It cannot be assumed, however, that counselling dupes workers and reduces them to passive and helpless victims, or that it purges their minds of any awareness of exploitation or humiliation. Instead, it shapes workers' subjectivity and configures the relationship between the self and external conditions in a specific way. It conditions them to develop a sense of agency, and a notion of making a choice and of being in control of their lives, not by challenging workplace conditions but by devising effective personal strategies to adjust to their circumstances. Managing oneself effectively in difficult conditions is here equated with exercising one's 
own agency. Not surprisingly, the "ability to accept" is cited by workers as a key quality required in security work, as mentioned above, and employers and official training manuals attach such high priority to "building positive attitudes".

\section{CONCLUSION: SOCIAL AND POLITICAL IMPLICATIONS}

As seen above, an informal workforce has developed and expanded within the formal sector, in order to meet the accelerating need for labour in the private corporate sector that has thrived in the context of globalization and economic liberalization in India from the ig9os onward. Organized informality has been facilitated by the systematic recruitment of the most deprived to serve at the lowest end of the urban economy in interactive services. The process of mobilization and formal training of labour, with state cooperation and sponsorship, and the "professionalization" of security and other urban low-end service staff, mark a novel development in the urban labour market. However, the terms of employment remain informal, precarious, without any effective state protection or regulation, and without any prospect of workers gaining a permanent foothold in the labour market or of upward mobility. This is consistent with the definition of the precariat as those with a "distinctive burden of insecurities", ${ }^{43}$ who are engaged in "insecure forms of labour that are unlikely to assist them to build a desirable identity or a desirable career", and who lack a "sense of development achieved through work and lifestyle". ${ }^{44}$

An integral feature of service work is the systematic inculcation of discipline and control of the body to produce a regimented work force, along with the training of the mind to develop the right kind of attitude to work and to endure the everyday subordination and subservience of labour to superior social orders. In the analytical literature, this has been referred to as the creation of a new "emotional proletariat", ${ }^{45}$ with employers controlling and directing, not just the physical labour of workers, but also their behaviour, conduct, and emotions. Such control of the body and mind in an organized, structured way through formalized training, extended collaboratively by the state and the private sector, was hitherto unknown in the Indian labour market and is an important new element of organized informality. While modern techniques of indirect control, by reshaping the worker's sense of self, are evident here, at the same time, these are reinforced by importing and reproducing pre-existing

43. Standing, The Precariat, p. vii.

44. Ibid, p. I6.

45. Cameron Lynne Macdonald and Carmen Sirianni, "The Service Society and the Changing Experience of Work", in idem (eds), Working in the Service Society (Philadelphia, PA, 1996), pp. I-26. 
forms of oppressive social custom and servility within the organized sector. Thus, the mental and bodily subservience of domestic work and of caste subordination, especially in rural contexts, that workers had expected to overcome in the corporate setting, continue to persist.

Crucially, however, this relates not so much to employers, but arises in interaction with customers and clients, who are the driving force in a consumer economy. Here in the interactive services, the affective expression of servility and its corporeal embodiment, as well as the management of one's own emotions, are more important than physical labour and manual toil. At the same time, various direct forms of labour discipline and coercion also persist. Further, contempt and antipathy directed towards workers reflect the increasingly evident hostility and animosity of the upper and middle classes towards the lower orders in globalized India, and mirror wider emerging processes of exclusion and marginalization of the urban poor. ${ }^{46}$

From the perspective of the workers, the most important feature of their experience of work is the culture of servility, "insult", and humiliation in everyday interaction with customers and clients - those with the economic power to consume and invest, in today's consumption- and enterprise-driven economy. This has not only served culturally to reinforce an unequal social and status hierarchy, but also deepened workers' awareness of social stratification, not least because the culture of servility here is at odds with India's prevailing democratic zeitgeist and runs counter to the norms and principles of equality and citizenship rights that underpin mass electoral mobilization. Gopal Guru points out that, in recent decades, the development of anti-caste and other emancipatory movements have led to "the emergence and the articulation of the language of rights [that] make the assertion against humiliation possible [...] by previously servile classes". ${ }^{47}$ This casts into sharp relief precisely the opposite trend of everyday degradation and diminution at the workplace. In the wider setting of deepening democracy, workplace identities come to be shaped less by employment relations, and more by antagonistic interactions with the moneyed classes at the site of interactive service work. Perception of class distinction is thus subjectively produced at the workplace through cultural and social exchange between workers and customers, rather than being generated through labour relations or being constituted through collective political action at the workplace. ${ }^{48}$

Despite sharpening social tensions, however, organized protests, collective political mobilization, acts of dissent or expression of discontent are, in fact, largely absent among the workforce. Instead, what might be

46. Fernandes, India's New Middle Class, ch. 4; Gooptu, "Economic Liberalization, Urban Politics and the Poor", pp. $3^{8-42 .}$

47. Gopal Guru, "Introduction: Theorizing Humiliation", in Guru, Humiliation, pp. I-19, 5. 48. For related arguments on class, see McDowell, Working Bodies, pp. 64-7I. 
called the "politics of the self" has become the order of the day. The emphasis on self-management, during training and at work, instils the notion among workers that survival in the labour market, and success or failure at work, are a matter of personal achievement or fault and of individual responsibility, as well as a product of one's own personality traits and acquired skills and competences, including mental or psychological ones. This displaces attention from workplace exploitation and the responsibility of employers or the state for the predicament of workers. Workers are trained to rely on their own inner resources and abilities to engage with everyday life and to take recourse to individualized and internalized coping strategies to respond to problems, without engaging with systemic and structural contradictions or seeking public or state action or engaging in any form of contentious politics. ${ }^{49}$

This privileges a politics of the self in which workers are enjoined to act on themselves and wage personal or private struggles, rather than public ones to confront external forces that affect their lives. It also inculcates a disposition to accept and adapt to existing conditions. Thus, individual efforts to strengthen oneself and self-development emerge as a form of politics in a personalized mode, with an attendant belief in the irrelevance of citizens' engagement with the state and involvement in conventional politics. In this way, the workplace serves as the site of production of self-reliant and selfdriven political subjects and citizens, consonant with the needs of a marketdriven economy and polity increasingly dominated by private corporate capital, ${ }^{50}$ with state abdication of the responsibility of protecting workers.

In other ways too, the reconfiguration of the meaning and practice of politics at the workplace has implications far beyond for Indian politics. Increasing mass participation in electoral politics in recent decades and the resilience of India's democratic polity are now widely acknowledged to be a product of the "democratic upsurge" of the poor and lower orders. ${ }^{51}$ As Javed Alam points out, "democracy in India survives not despite the illiterate and poor people, but due to their pressures for democratic governance". 52 Developments at the workplace of the kind seen here, with an emphasis on individualized and personalized politics, may well encourage democratic disengagement or apathy of the most

49. For a variety of theoretical perspectives and discussion on comparable processes of individualization in the West, see Ulrich Beck and Elisabeth Beck-Gernsheim, Individualization (Los Angeles, CA [etc.], 2002), chs 2, 3; Cosmo Howard, "Introducing Individualization" and "Three Models of Individualized Biography", in idem (ed.), Contested Individualization: Debates about Contemporary Personhood (New York, [etc.], 2007), pp. I-43; Bauman, Liquid Modernity; Ulrich Beck, The Brave New World of Work (Cambridge, 2000), pp. 53-56, 75.

50. Atul Kohli, Poverty Amid Plenty in the New India (Cambridge [etc.], 2012), ch. 2.

5. Yadav, "Understanding the Second Democratic Upsurge", pp. I 20-I45.

52. Alam, "What is Happening Inside Indian Democracy?", p. 95. 
actively mobilized democratic classes, and thus reverse or stall the existing political current of democratization in India.

\section{TRANSLATED ABSTRACTS FRENCH - GERMAN - SPANISH}

Nandini Gooptu. Sentinelles serviles de la cité: gardes de la sécurité privée, informalité organisée et travail dans les services interactifs dans l'Inde mondialisée.

Par le biais d'une étude sur les gardes de la sécurité privée dans l'Inde urbaine, cet article examine certains processus de travail émergents dans le secteur de plus en plus dominant des entreprises privées dans les économies émergentes du Tiers-Monde, dans le sillage de la libéralisation et de la mondialisation économiques. Afin de satisfaire au besoin croissant de services interactifs, un ample cadre de travailleurs sous-payés et occasionnels est apparu, travaillant sous un régime d'informalité organisée. Ici, le recrutement et la formation sont systématiquement institutionnalisés et formalisés par des organismes privés, avec l'imprimatur de l'État, mais les relations de travail restent informelles et précaires. L'article étudie des formes de subordination de la maind'œuvre et une culture de la servilité sur le lieu de travail, ainsi que le travail incorporé et la main-d'œuvre survoltée qui caractérisent les bas emplois dans les services. L'article montre comment la subjectivité politique des travailleurs et leur perception de la différence de classe et d'identité sociale sont modelées par l'interaction sociale et culturelle au travail, et comment ces aspects se rattachent à une politique démocratique et une citoyenneté plus larges.

Traduction: Christine Krätke-Plard

Nandini Gooptu. Dienstbare Stadtwächter: Private Sicherheitskräfte, organisierte Informalität und die Arbeit im interaktiven Dienstleistungssektor des globalisierten Indiens.

Am Beispiel privater Sicherheitskräfte im städtischen Indien untersucht dieser Beitrag die neueren Arbeitsprozesse im zunehmend dominanten privatwirtschaftlichen Sektor aufsteigender Drittwelt-Ökonomien, wie sie sich im Gefolge wirtschaftlicher Liberalisierung und Globalisierung entwickelt haben. In Reaktion auf die wachsende Nachfrage nach Arbeitskräften im Bereich interaktiver Dienstleistungen ist ein umfassendes Heer gering entlohnter Gelegenheitsarbeiter entstanden, die einem Regime organisierter Informalität unterliegen. Anwerbung und Ausbildung werden von privaten Agenturen mit Zustimmung des Staates systematisch institutionalisiert und formalisiert, doch die Beschäftigungsverhältnisse bleiben informell und unsicher. Der Beitrag untersucht die Formen der Arbeitsunterwerfung und die Kultur der Dienstbarkeit am Arbeitsplatz sowie die verkörperte und emotionale Arbeit, die für die niederen Ränge des Dienstleistungssektors charakteristisch ist. Dabei wird gezeigt, wie die politische Subjektivität der Arbeiter und ihre Wahrnehmung von Klassenunterschieden und sozialer Identität von der kulturellen und sozialen Interaktion am Arbeitsplatz geprägt sind, und wie sie sich zum weiteren Zusammenhang demokratischer Politik und Staatsbürgerschaft verhalten. 
Nandini Gooptu. Los serviles centinelas de la ciudad: guardias de seguridad privada, informalidad organizada y servicios de trabajo interactivo en la India globalizada.

Mediante el estudio de los guardias de seguridad privados en la India urbana, este artículo analiza procesos laborales que afloran en el cada vez más dominante sector privado empresarial en las economías emergentes del Tercer Mundo, en el despertar de la liberalización económica y la globalización. Para hacer frente a la necesidad creciente de trabajo en los servicios interactivos, ha surgido un extenso grupo de trabajadores eventuales mal retribuidos, trabajando bajo un régimen de informalidad organizada. La contratación y la formación están sistemáticamente institucionalizadas y formalizadas por agencias privadas, con el consentimiento del Estado, pero las relaciones laborales siguen siendo caracterizadas por la informalidad y la precariedad. El texto examina tanto las formas de subordinación laboral y una cultura de servilismo en el espacio de trabajo como las características de exigencia corporal, de apariencia física y de actitud emocional de estos trabajos de servicios de baja cualificación. El artículo muestra cómo la subjetividad política de los trabajadores y su percepción de las diferencias de clase y de la identidad social toman forma a partir de una interacción cultural y social en el trabajo y cómo estos se relacionan con un sentido más amplio de la política democrática y la ciudadanía.

Traducción: Vicent Sanz Rozalén 